International Business and Global Economy 2019, no. 38, pp. 56-77

Biznes międzynarodowy w gospodarce globalnej 2019, nr 38, s. 56-77

Edited by the Institute of International Business, University of Gdańsk

ISSN 2300-6102

e-ISSN 2353-9496

DOI 10.4467/23539496IB.19.004.11503

Kamran Davari Nikou

Dokuz Eylül University, Graduate School of Social Sciences

\title{
A cross-national survey on norm and nature of idea generation in new product development
}

The nature of idea generation in new product development is challenging, competing, risky, and requires an interdisciplinary approach. Being aware of the types, sources, techniques, and metrics of ideation is crucial for the achievement of effective and efficient idea generation. The present research attempts to identify the support mechanisms used within different national cultures in terms of generating new product ideas. A descriptive survey was conducted in order to exemplify idea generation norms in new product development and to establish the nature of this process from a multidisciplinary perspective. Then, an explorative qualitative research was carried out with the participation of 78 experts from 39 countries. Subsequently, partial raw data were refined, categorized, and interpreted via content analysis. The literature on idea generation in new product development ought to be more explorative rather than confirmative; it also needs to adopt a wider perspective because of the multidisciplinary nature of the phenomenon it is concerned with. Since successful idea generation can be cultivated along with the development of human capital, more importance should be attached to interdisciplinarity in human resources, multidisciplinarity in human skills, and perceptual vision than to technical excellence.

Keywords: high-tech, idea generation, nature, new product development, new service development

JEL classification: A12, M1, M31, O14, O32

\section{Międzynarodowe badania standardów i cech generowania pomysłów na nowe produkty}

Obszar generowania pomysłów w rozwoju nowych produktów jest pełen wyzwań, cechuje się wysoką konkurencyjnością i ryzykiem, a przy tym ma charakter interdyscyplinarny. Znajomość typów, a także właściwych technik i wskaźników tworzenia idei jest kluczowa w procesie skutecznego generowania pomysłów. Celem niniejszego artykułu jest określenie mechanizmów wspierających generowanie pomysłów na nowe produkty w różnych kulturach. Aby zilustrować standardy obowiązujące w procesie generowania pomysłów na nowe produkty i określić naturę tego procesu z perspektywy multidyscyplinarnej, przeprowadzono badanie ankietowe. Przeprowadzono także eksploracyjne badanie jakościowe z udziałem 78 ekspertów z 39 krajów. Następnie pozyskane $\mathrm{w}$ badaniach dane surowe zostały skategoryzowane i zinterpretowane poprzez zastosowanie metody analizy treści. Literatura dotycząca generowania pomysłów w rozwoju nowych produktów powinna mieć charakter bardziej eksploracyjny niż potwierdzający, a także obejmować szersze spojrzenie i uwzględniać multidyscyplinarną naturę tego zjawiska. Ponieważ proces tworzenia idei postępuje wraz z rozwojem kapitału ludzkiego, szczególnie ważne jest 
położenie większego nacisku na interdyscypliność zasobów ludzkich, multidyscyplinarność kompetencji miękkich oraz wizję niż na doskonałość techniczną.

Słowa kluczowe: high-tech, generowanie pomysłów, rozwój nowych produktów, rozwój nowych usług

Klasyfikacja JEL: A12, M1, M31, O14, O32

\section{Introduction}

Effectual new product development (NPD) is crucial for competition and longrun viability in our turbulent business environment [Paashuis, 1998, p. 1; Calantone, Schmidt, Song, 1996, p. 342; Song, Neeley, Zhao, 1996, p. 546]. An inalienable component of NPD procedure is idea generation. Nearly all of NPD practices begin with idea generation and finish with commercialization or production [Davari Nikou, 2017, p. 302]. Gupta and Wilemon [qtd. in: Bacon et al., 1994, p. 32] posit that the initial stages of the development of new products critically affect the length of the time required to introduce a new product or service to the market. A vigorous and competent 'product definition' derives from accurate and rigorous idea generation. Since idea generation is a substantial factor for new product development, giving it due recognition could be advantageous. The paper attempts to clarify the norms and nature of idea generation for new product development as well as its types, applications, sources, and techniques from a cross-cultural viewpoint. After clarifying the nature of NPD idea creation from a multidisciplinary perspective with the use of a descriptive survey, the paper explicates the scarcity of literature on the subject. Then, it presents a cross-cultural comparison based on an exploratory research, and ends with a discussion and conclusion of findings.

\section{Methodology}

The study explores the concept of idea generation in new product development and attempts to identify the support given to it by national cultures from an interdisciplinary perspective. A qualitative approach is applied because of the exploratory character of the study. It is also suitable for answering complex humanistic "'why" and "how" type questions' [Marshall, 1996, p. 522]. The major question the study asks is: What effect national cultures have on generating new product ideas?

How could national cultures of different countries be compared in terms of creating new product ideas? The study is focused on idea generation in high-tech companies of all sizes (micro, small, medium, and large). In view of the fact that 
the research is explorative, and its subject specific and specialized, the expert-opinion technique was used. The term 'expert' here encompasses: directors of NPD projects, managers of NPD departments, NPD executives, NPD experts, NPD coaches or mentors, TCOs, R\&D managers, idea midwives, etc. Judgmental sampling [Babbie, 1990, p. 97; Jones, 1955, p. 766] and purposive (purposeful) sampling [Latham, 2007, p. 8; MacNealy, 1999, p. 157] was carried out to select the respondents. The respondents were allowed to hand the questionnaire over to other experts in the same field of research using the snowball sampling (chain sampling) method. A systematic review of literature was conducted to collect secondary data. The questions were pre-tested in a pilot study with a limited number of respondents. Primary data were gathered via in-depth interviews and, in some cases, mail surveys with 78 experts from 39 countries between February 2016 and December 2016. Content analysis was applied to the answers. The theme is the most productive unit for content analysis, inasmuch as 'issues, values, beliefs and attitudes are usually discussed in this form' [Kassarjian, 1977, p. 12]. The determining specifications of content analysis have to be systematic, objective, and quantitative [Kassarjian, 1977, p. 9; Holsti, 1969, p. 5; Budd, Thorp, Donohew, 1967, p. 2]. Primary data was collected until the point of data saturation, which is when a study achieves 'sufficient depth' [Baumberg, 2012, p. 37] and adding new responses scarcely provides surprising or new information [Galvin, 2015, p. 3].

\section{Literature review}

\subsection{Etymology and semiology}

The word 'idea' originated from Greek, from the root of idein, 'to see', and idea means 'form or pattern'. The word 'idea' takes several meanings depending on the context in which it is used, for instance 'a thought, an impression, an opinion, a plan of action, an intention, a belief, a groundless supposition, conception, notion, view or fantasy' (Oxford English Dictionary), 'any conception existing in the mind as a result of mental understanding' (Dictionary.com), 'something that you imagine or picture in your mind' (Merriam-Webster Dictionary), 'a suggestion or plan for doing something', 'an understanding, thought or picture in your mind' (Cambridge Business English Dictionary), or 'a thought that you have about how to do something or how to deal with it' (Macmillan Dictionary). 'Generation' has different meanings as well, but for the purposes of this study we will use it in its proper understanding as 'the process of coming or bringing into being' (Merriam-Webster Dictionary) and 'the process of producing something' (Macmillan Dictionary). 


\subsection{Definitions}

Numerous meanings of 'idea generation' can be found in different sources, such as 'the process of creating, developing and communicating ideas which are abstract, concrete, or visual' as well as 'the process of constructing through the idea, innovating the concept, developing the process, and bringing the concept to reality' (Business Dictionary) or 'the process of creating new ideas about products, services, advertising, systems, etc.' (Cambridge Business English Dictionary). Idea generation can be understood as a systematic pursuit of the creation, growth, development, maturation, and refinement of a concrete idea [Bhuiyan, 2011, p. 754]. Foster posits that ideas are "feats of association", "unexpected likenesses", "new wholes", "shake together" then "select among", "bi-sociations" and new (or unlikely) "juxtapositions"' [Foster, 2009, p. 7]. Idea generation as a singular stage of new product development could be defined as the process of finding or constructing fresh ideas about goods, services, processes, and systems aimed at conveying the mental concept to real world. Some authors prefer to use the term 'ideation' instead of 'idea generation' [Losito, 2012, p. 6; Kudrowitza, Wallace, 2012, p. 2; Toubia, 2006, p. 411; Shah, Vargas-Hernandez, 2003, p. 111]. Furthermore, idea management has been described as the path to identifying the needs for ideas as well as producing and assessing them [Vandenbosch, Saatcioglu, Fay, 2006, p. 260]. The creativity of new product ideas could also be taken to mean the degree of novelty relative to competing alternatives [Dean, Griffith, Calantone, 2016, p. 39; Fang, 2008, p. 90].

\subsection{Metaphors of idea generation}

Idea generation could be described with the use of metaphors: Peter Drucker used a metaphor to explain the nature of innovative ideas, stating that they are similar to 'frogs' eggs; of a thousand hatched; only one or two survive to maturity' [qtd. in: Stasch, Lonsdale, Lavenka, 1992, p. 14]. Jacob Goldenberg and David Mazursky refer to Darwin's theory of evolution using an analogical approach, claiming that products develop in a reaction to 'environmental pressure' in terms of market needs, wants, demands, and desires, and finally it's 'the survival of the fittest' [Goldenberg, Mazursky, 2002, p. 23]. Wulfen [2016] states that 'ideas are similar to tulip bulbs; nobody knows which one will blossom into a beautiful flower'. All cooks use similar flours, beans, vegetables, meats, spices, and cookery tools, but the taste of the meals differs from one cook to another, depending on the idea, plan, sequence, and not only on the ingredients used. 


\subsection{Why is idea generation crucial?}

A new product kick-off launches at the moment of idea generation [Bingham, Quigley, 1989, p. 50]. Idea generation is said to be the 'key' or 'heart' of creativeness [Aaker, Batra, Myers, 1992, p. 372]. Every 'innovation begins with an idea' [Vandenbosch, Saatcioglu, Fay, 2006, p. 260]. Moreover, innovation is regarded as the 'prime engine of growth' [Krishna, Kautish, 2012, p. 119]. Thus, paying little attention to ideation may prove to be more expensive and time-consuming in the end, because these initial stages of problem identification, idea generation, concept development, screening and selecting ideas are pivotal for the achievement of the next phases of the new product development process [Shekar, 2007, p. 4]. Fresh ideas could be seen as the wheel of progress [Foster, 2009, p. x] and the raw material for product development [Rochford, 1991, p. 287]. The goal of the entire idea generation effort is 'to guarantee that the company does not leave the exploration stage of new product development to chance' [Stasch, Lonsdale, LaVenka, 1992 , p. 3]. Idea generation in NPD is important for finding out a company's next killer products [Ozer, 2002, p. 2]. Customer-driven corporations investigate customers' desires, collect new product or service ideas, and evaluate suggested 'product improvements' [Kotler, Armstrong, 2003, p. 22].

\subsection{Applications of idea generation}

Idea generation has numerous applications in several fields from making spontaneous individual decisions to managing complicated interdisciplinary universal crises. An idea is basically something that is yet unrealized, unproven, or untested, and can still allow for some degree of change. It emerges as an answer to some unrealized aim [Gurteen, 1998, p. 2], and thus the first application of idea generation is the realization of this unrealized aim. Applications of idea generation are varied and the ideas themselves can be categorized into ideas to solve problems, ideas to help people, ideas to save, fix and create things, ideas to make things better and cheaper, ideas that enlighten, invigorate, inspire, enrich and embolden' [Foster, 2009, p. xi]. Some interpretations tie idea generation with economic value creation through 'putting new ideas into commercial use' [Atkinson, Wial, 2008, p. 6]. Idea generation encompasses any changes of new products or services [Glassman, 2009, p. 18] and kicks off the process of new product development [Bingham, Quigley, 1989, p. 50]. Simply put, innovation could be described as an efficacious utilization or application of fresh ideas to products, services, and processes [Zhang, Dodgson, 2007, p. 45]. Idea generation based on research and development creates conditions required to ensure the 'development of original products, product improvements, product modifications and new brands through the firm's own R\&D efforts' [Kotler, Armstrong, 2003, p. 322]. Businesses, organi- 
zations, and individuals alike need to come up with original, virgin, and breakthrough ideas; that is why 'revolutionary idea generation' - a radical ideation technique consisting in discarding all prior knowledge about a given problem and coming up with fresh solutions or recommendations [Tanțău, Mateeşescu, 2012, p. 64] and, moreover, identifying next killer products - is imperative not only for high-tech companies but also other businesses [Ozer, 2002, p. 2].

\subsection{Sources of an idea}

Ideas for new products could be arrayed in a wide range because the sense of novelty and the degree of newness differs from one man to another [Blythe, 1999, p. 419]. Generating a large quantity of ideas [Aaker, Batra, Myers, 1992, p. 372] is a common and frequently used approach in the quest for fresh and worthy ideas [Goldenberg, Mazursky, 2007, p. 290]. Likewise, combination, amalgamation, or integration of two or more already existing ideas could be a rich source of new ideas. Especially the merging or blending of capable ideas would be a fruitful and customer-friendly approach to new service development (NSD). Nicholas Negroponte asks [qtd. in: Foster, 2009, p. 7], 'Where do good new ideas come from? That's simple - from differences. Creativity comes from unlikely juxtapositions'. Andy Warhol (American artist and the leading face in the visual art movement known as pop art) believed that an array of multiplied representations of the same object can be more interesting and alluring than the same object viewed in isolation. Thomas Ward, Steven Smith, and Ronald Finkle [1999] suggested a model of creative cognition called the 'Geneplore model' - an amalgamation of a generative and explorative approach set within a widely understood descriptive-heuristic framework rather than 'an explanatory theory of creativity'. The traits of the final new product can be determined by either explorative or generative aspects [Ward, Smith, Finkle, 1999, p. 191]. New product ideas can originate from various sources. Some of them are presented by members of the staff and thus have an internal origin. Others have an external origin and are the result of market and consumer research. Customers can therefore be an important source whose input leads to the 'identification of untapped needs' [Palmer, 2009, p. 281]. 'Watching and listening to consumers' is a major source of new product ideas, too [Kotler, Armstrong, 2003, p. 325]. Innovation is still considered as the prime motivator of growth, yet consumers play a dominant role in 'shaping innovation strategy and execution' [Krishna, Kautish, 2012, p. 119]. It is consumers who most frequently come up with ideas for new products [Kilinc, Dogan, 2012, p. 165] and are the best external source of ideas, while the most lucrative internal sources include research and development units and marketing departments [McAdam, McClelland, 2002, p. 120]. Customer involvement should therefore be perceived in terms of a repetitive 'dialogue and collaboration' [Krishna, Kautish, 2012, p. 120]. Lack of commu- 
nication between different levels of an organization may hinder the flow of ideas. J. Fred Bucy (former president of Texas Instruments) proposed a technique for carrying through ideas from inception to implementation, which he named IDEA (identify, develop, expose, and act), in order to ensure that good ideas are not overlooked and squandered because of lack of proper communication [No name, 1971, p. 45]. Numerous new product ideas originate from 'blue sky' science centres whose real goal is not to improve the process of consumer-driven product development, but to further the progress in a certain field of science or technology. Occasionally, new product ideas can emerge quite suddenly without any prior preparation, early arrangements with potential buyers, or market analysis [Palmer, 2009, p. 282]. Nowadays, ideas for new products are generated and evaluated in what is called 'idea markets', which use virtual idea stocks, allowing market participants to buy shares through a virtual market. These transactions or portfolio values then serve as indicators of the quality and value of new product ideas [Soukhoroukova, Spann, Skiera, 2007, pp. 3-10]. Idea markets provide a platform for presenting, selecting, sourcing, and sieving ideas, and thus serve to filter out poor ideas and increase the efficiency of NPD [Soukhoroukova, Spann, Skiera, 2012, p. 100]. Game theory has the potential to be a powerful source of ideas. Economists have developed the logic and principles of game theory and on this basis, after years of trial and error, they have come up with proven strategies which now influence the mind-set of businessmen, military tacticians, natural scientists, and even sports coaches [Miller, 2003, p. 2]. 'Pre-selection mechanisms based on the collective intelligence' [Schemmann et al., 2016, p. 1148], 'wisdom of the crowds' [Surowiecki, 2005, p. 277], and 'crowd-sourcing: using an online, distributed problem-solving and production model to leverage the collective intelligence of online communities to serve specific organizational goals' [Brabham, 2013, p. 117] are new sources of product ideas. Although the process of group ideation is frequently hindered by certain societal and intellectual factors, properly managed group idea exchange can be extremely efficient [Paulus, Brown, 2007, p. 248]. 'Direct customer requests', 'follow-up of the customers' problems', and 'acquisition of customer feedback' [Toivonen, Tuominen, 2007, p. 895] as well listening to the voice of the customer, are the tools of customer-centric idea generation. 'Co-creation, quick and dirty prototypes, re-use design knowledge' [Herring, Jones, Bailey, 2009, p. 3], 'co-development and collaboration among firms' [Karniouchina, Victorino, Verma, 2006, p. 279], 'business environmental scanning', 'creativity to the interpretation of trend analysis' [Kohn, 2004, p. 688], 'alliance network composition', and 'informal network constellation' are the main elements of successful innovative ideation [Ahuja, 2000, p. 425; Baum, Calabrese, Silverman, 2000, p. 267]. Freedom in the area of innovation, the use of cross-functional teams in the NPD process, and avoidance of short-termism favour idea generation [Trot, 2002]. 
Besides, 'tolerance for ambiguity and deviant ideas' positively influences team innovativeness [De Mooij, 2011, p. 122]. It is considered beneficial to conduct forecasting trials in the NPD process in the pre-launch phase. Involvement in 'new product forecasting process, forecast accuracy and forecast time horizon' facilitate generation of up-to-date product ideas [Kahn, 2002, p. 133]. 'Primitive predictive guidelines' act as indicators of the future success of new product ideas. It is crucial to evaluate the degree of acceptance for an idea before launching next phases of new product development and keep improving products that have big potential for success [Goldenberg, Lehmann, Mazursky, 2001, p. 69]. Ken Kamoche and Miguel Pina e Cunha explain the interesting issue of how jazz improvisation can be applied to product innovation and conclude that improvisation in all performance arts is the source of novelty, creativity, and incessant learning [Kamoche, Pina e Cunha, 2001, p. 756].

\subsection{Techniques of idea generation}

Knowing and using ideation techniques, a set of which is presented below, is crucial for efficient idea creation, idea screening, and idea management. Doubtless the usability of each method differs and depends on contingency and particular circumstances, but being aware of these techniques and using them separately or in combination is always beneficial for people involved in NPD.

Table 1. 200 prevalent tools of idea generation in NPD

\begin{tabular}{|l|l|l|}
\hline \multicolumn{1}{|c|}{ Class } & \multicolumn{1}{|c|}{ Tools } & Number \\
\hline & $\begin{array}{l}\text { affinity method } \\
\text { balanced score cards (BSC) } \\
\text { buddy checks } \\
\text { coaching } \\
\text { consulting } \\
\text { decision tree analysis } \\
\text { disaster planning } \\
\text { enterprise resource planning (ERP) } \\
\text { gallery method } \\
\text { heuristic ideation technique } \\
\text { management } \\
\text { perspective }\end{array}$ & $\begin{array}{l}\text { Impact-value analysis } \\
\text { Ishikawa analysis (fishbone diagrams) } \\
\text { kiss (keep it short and simple!) } \\
\text { KJ method (Jiro Kawakita tool or affinity graph) } \\
\text { mentoring } \\
\text { nature symbol (nature metaphor) } \\
\text { overseas sister company } \\
\text { overseas store visits } \\
\text { Pareto analysis } \\
\text { prioritization process } \\
\text { socio-drama }\end{array}$ \\
\hline
\end{tabular}




\begin{tabular}{|c|c|c|}
\hline Class & Tools & Number \\
\hline & $\begin{array}{l}\text { total quality management (TQM) } \\
\text { weighted score matrix } \\
1 \mathrm{H} 5 \mathrm{~W}\end{array}$ & \\
\hline $\begin{array}{l}\text { innovative } \\
\text { perspective }\end{array}$ & $\begin{array}{l}\text { absence thinking } \\
\text { accidental genius } \\
\text { alternate scenarios } \\
\text { backward ideation } \\
\text { Battelle Buildmappen Brainwriting (BBB) } \\
\text { be number one } \\
\text { bi-wordal } \\
\text { brain borrow } \\
\text { brain storming } \\
\text { change the words } \\
\text { connecting the unconnected } \\
\text { counter models } \\
\text { daydreaming } \\
\text { diffusion models } \\
\text { Delphi technique } \\
\text { exaggerate it } \\
\text { excerpt excitation } \\
\text { forced association (forced relationship) } \\
\text { free association } \\
\text { idea advocate } \\
\text { idea competition } \\
\text { idea midwife } \\
\text { idea shopping (idea market) } \\
\text { ideas shower } \\
\text { IDEA technique (identify, develop, expose, act) } \\
\text { ideatoons handouts } \\
\text { incubation and relaxation (sleeping) } \\
\text { internal and external expert opinion } \\
\text { lateral thinking } \\
\text { lotus blossom } \\
\text { nominal group technique } \\
\text { passive searching } \\
\text { random input } \\
\text { random stimulation } \\
\text { role playing } \\
\text { SCAMPER } \\
\text { semantic intuition } \\
\text { six thinking hats } \\
\text { solo brainstorming } \\
\text { story-telling workshops } \\
\text { SWOTRIZ } \\
\text { synectics } \\
\text { thinking out of the box (throw the box) } \\
\text { transpose the words } \\
\text { what if questions } \\
\text { wish list } \\
\text { 360 degree thinking }\end{array}$ & 47 \\
\hline
\end{tabular}




\begin{tabular}{|c|c|c|}
\hline Class & Tools & Number \\
\hline $\begin{array}{l}\text { risk orientation } \\
\text { perspective }\end{array}$ & $\begin{array}{l}\text { critical path method (CPM) } \\
\text { TOWS matrix } \\
\text { extreme value analysis } \\
\text { failure mode effects analysis (FMEA) } \\
\text { fault tree analysis } \\
\text { computerized prediction models } \\
\text { risk assessment matrix }\end{array}$ & 7 \\
\hline $\begin{array}{l}\text { R\&D, E\&D } \\
\text { perspective }\end{array}$ & $\begin{array}{l}\text { analytical hierarchy process (AHP) } \\
\text { artificial neural networks } \\
\text { attribute listing } \\
\text { collaborative sketching (C-Sketch) } \\
\text { computer-aided design (CAD) } \\
\text { concurrent engineering } \\
\text { design for X (DFX) } \\
\text { design mock-up } \\
\text { design of experiments (DOE) } \\
\text { dirty mock-ups } \\
\text { evaluation matrix } \\
\text { expert systems } \\
\text { intellectual property quest (patent, registered sign) } \\
\text { manufacturing resource planning (MRP) } \\
\text { morphological analysis } \\
\text { paper mock-ups } \\
\text { poka-yoke (zero defect) } \\
\text { quality function deployment (QFD) } \\
\text { rapid prototyping } \\
\text { reengineering } \\
\text { reverse engineering } \\
\text { statistical process control (SPC) } \\
\text { Taguchi methods } \\
\text { technology road map } \\
\text { theory of inventive problem solving (TRIZ) } \\
\text { value engineering }\end{array}$ & 26 \\
\hline general perspective & $\begin{array}{l}\text { anonymous voting } \\
\text { benchmarking studies } \\
\text { bionics } \\
\text { brain writing } \\
\text { change of perspective } \\
\text { checklists } \\
\text { focus group/unfocus group } \\
\text { force field analysis } \\
\text { free elicitation } \\
\text { gallery method } \\
\text { games theory } \\
\text { gap analysis } \\
\text { group discussion } \\
\text { group dynamics } \\
\text { group passing technique } \\
\text { PINC filter } \\
\text { redefinition } \\
\text { scoring tools (idea screening) }\end{array}$ & 21 \\
\hline
\end{tabular}




\begin{tabular}{|c|c|c|}
\hline Class & Tools & Number \\
\hline & $\begin{array}{l}\text { weighting, scoring, voting method } \\
\text { what if questions } \\
6-3-5 \text { technique }\end{array}$ & \\
\hline $\begin{array}{l}\text { financial leverages } \\
\text { perspective }\end{array}$ & $\begin{array}{l}\text { activity based costing (ABC) } \\
\text { benefit/cost analysis } \\
\text { breakeven point analysis } \\
\text { cash flow forecasting } \\
\text { estimated commercial value (ECV) } \\
\text { financial leverages analysis (IRR, NIBT, NPV, ROI, DCF) } \\
\text { hundred euro test }\end{array}$ & 7 \\
\hline $\begin{array}{l}\text { marketing } \\
\text { perspective }\end{array}$ & $\begin{array}{l}\text { behaviour mapping } \\
\text { Boston consulting group's matrix (BCG matrix) } \\
\text { brand personification } \\
\text { considering the meta market } \\
\text { consumer journey } \\
\text { crowd-sourcing } \\
\text { COCD box (centre for development of creative thinking) } \\
\text { connecting unconnected } \\
\text { ethnography considerations } \\
\text { excursion technique } \\
\text { extreme user interviews } \\
\text { FAN study (feasibility, attractiveness, and novelty) } \\
\text { FUB test (feasible, useful, and beautiful) } \\
\text { FUN test (feasible, useful, and new) } \\
\text { Kano model } \\
\text { market research and customer analysis } \\
\text { Porter's five forces } \\
\text { Porter's generic strategy (focus, differentiation, cost leadership) } \\
\text { projective techniques } \\
\text { thematic apperception test (TAT) } \\
\text { voice of the customer (VOC) } \\
\text { white space } \\
\text { word association }\end{array}$ & 23 \\
\hline $\begin{array}{l}\text { futurology } \\
\text { and foresight } \\
\text { perspective }\end{array}$ & $\begin{array}{l}\text { forecasting matrix } \\
\text { formulation } \\
\text { future user } \\
\text { future telling } \\
\text { historical analysis } \\
\text { modelling } \\
\text { monitoring } \\
\text { normative private styles } \\
\text { progression curves } \\
\text { regression analysis } \\
\text { scenario development \& analysis } \\
\text { simulation } \\
\text { trend analysis } \\
\text { trend monitoring } \\
\text { trend projection } \\
\text { visionary techniques or visioning }\end{array}$ & 16 \\
\hline
\end{tabular}




\begin{tabular}{|c|c|c|}
\hline Class & Tools & Number \\
\hline $\begin{array}{l}\text { strategic } \\
\text { perspective }\end{array}$ & $\begin{array}{l}\text { Ansof's Matrix } \\
\text { change paths } \\
\text { context maps } \\
\text { crowd clovers maps } \\
\text { dark horse prototype } \\
\text { Darpa hard test } \\
\text { generational arcs } \\
\text { Gordon technique } \\
\text { Janus cones } \\
\text { pathfinders } \\
\text { PESTEL } \\
\text { TEMPLE } \\
\text { SWOT analysis } \\
\text { weak signal analysis }\end{array}$ & 14 \\
\hline $\begin{array}{l}\text { knowledge } \\
\text { management } \\
\text { perspective }\end{array}$ & $\begin{array}{l}\text { Box-Jenkins models } \\
\text { databases } \\
\text { data mining } \\
\text { decision support system (DSS) } \\
\text { decision trees } \\
\text { decomposition (dissection) } \\
\text { dialectical approaches } \\
\text { document management system } \\
\text { expert opinion } \\
\text { formulation } \\
\text { management information system } \\
\text { mind mapping } \\
\text { pre-cursor method (correlation method) } \\
\text { questioning assumptions } \\
\text { web browsers }\end{array}$ & 15 \\
\hline
\end{tabular}

Source: Own elaboration based on more than 40 sources.

\subsubsection{Mini-case example}

Benchmarking and learning from other people's best practices and paramount experiences always has been a rich fountain for idea generation. Recently Toyota Company arranged an activity to catch children's ideas trough an intellectual art contest. The company invited children from every continent, any race, any background of skill, any country and any social cast, then asked them to paint their desired car. The paintings are valued by R\&D department, designers, and NPD executives as primary drafts or pre-plans. The company has been organising the contest since 2004 under the name of "Toyota Dream Car Art Contest". Many lessons could be learned from this mini-case: inspiration from fresh minds, looking through a child's eye, modifying new products by taking into account views of potential customers, empathy and sympathy with the next generation, investing now in order to benefit in the future, defining and designing user friendly products based on children's feelings, inspirations and dreams, intensify- 
ing and deepening corporate social responsibility, enhancing memorable and emotional junction between potential customers and the brand image via experiential marketing and finally boosting brand credibility and customer loyalty.

Table 2 illustrates the key points of Toyota Dream Car Art Contest mini-case.

Table 2. Mini-case of Toyota Dream Car Art Contest

\begin{tabular}{|l|l|}
\hline \multicolumn{1}{|c|}{ Queue } & \multicolumn{1}{c|}{ Description } \\
\hline What & Toyota Dream Car Art Contest \\
\hline When & annually, since 2004 \\
\hline Where & throughout the world \\
\hline Who & children from all corners of the globe \\
\hline Why & $\begin{array}{l}\text { nurturing the creativity of the next generation of inventors, thinkers and dreamers, } \\
\text { a chance to feel the joy and power of a dream since every great idea was born in } \\
\text { the glimmer of a dream }\end{array}$ \\
\hline How & to share ideas about the future of mobility by drawing their dream cars \\
\hline Motto & "Draw your dream, drive the future" \\
\hline
\end{tabular}

Source: Own elaboration adopted from Toyota official website.

\subsection{Typology of idea generation}

Knowing 'how to think' is more important than knowing 'what to think' [Michalko, 2011, p. 13]. According to Jung [qtd. in: Avital, Osch, 2013, p. 121], typology of ego-functions is the basis of ideation: 'thinking, feeling, sensing and intuiting'. Creativity comes from divergent thinking, meanwhile innovation (put creativity into act) results from convergent thinking [Gurteen, 1998, p. 6]. 'Making novel combinations, thinking fluently, connecting the unconnected, looking at the other side, looking in other worlds, finding what you are not looking for and awakening the collaborative spirit' generates variations of the main idea [Michalko, 2011, p. 10]. The Geneplore pattern is composed of generative and explorative efforts [Shah, Vargas-Hernandez, 2003, p. 115] and sees creativity as the output of the mental process [Finke et al., 1996, p. 3]. The patterns of generative processes include: 'association, categorical reduction, analogical transfer, mental synthesis and transformation'. The exploratory route includes: 'attribute finding, conceptual interpretation, contextual shifting, functional inference, hypothesis testing' and quest for restrictions [Shah, Kulkarni, Vargas-Hernandez, 2000, p. 378]. Formal idea generation is categorized into two classes: logical and intuitive. Logical (rational) approach implicates systemic and methodical dissection of problems. Intuitive idea generation (types of which are: hybrid, germinal, transformational, progressive, and organizational) works by triggering the unconscious thinking procedures. The result is pretty unpredictable, but might help in coming up with fresh solutions [Shah, Kulkarni, Vargas-Hernandez, 2000, pp. 112, 377]. 


\subsection{The nature of NPD idea generation}

The nature of new product development makes it a very risky process. Several researchers have pointed to its low rate of success as well as high percentage of failed NPD projects [Safarzadeh et al., 2012, p. 8] due to 'the competing nature of idea-generation processes' [Morgan et al., 2015, p. 734]. According to some statistics, only ' $3 \%$ of new ideas are distinctively successful and just only $4 \%$ are mildly fertile and the rests evaporate' [Higgins, 2008, p. ii]. New products' failure ratio reaches to $90 \%$ [Hanna et al., 1995, p. 33]. A common complain about NPD idea generation is the $5 \%$ success ratio even after of creating thousands of new ideas [Hobcraft, 2011, p. 2]. New products chase failing with an alarming rate; therefore NPD executives should be better also faster at new product introduction in today's turbulent trade ambience [Flint, 2002, p. 305]. Ideation aimed to develop new products is too similar to a continuous competition so creating and valuing fresh ideas and collaborating with R\&D and others [Kotler, Keller, 2006, p. 634] play a dominant role in NPD process. 'The art of idea harvesting' is a new entered phrase into the NPD literature which refers to catching and stocking ideas that arise from several origins and transforming those to value [Pikkarainen et al., 2011, p. 20] by combination of normative or exploratory view. 'Normative creativity' focuses on creating ideas to decipher particular problems, essentials and intentions. 'Exploratory creativity' engenders a wide-range of ideas, which may not be certainly connected to recognized necessities or demands [Flynn et al., 2003, p. 420]. Product innovation in SMEs usually is directed by 'entrepreneurial logic of effectuation' also 'managerial logic of causation' [Berends et al., 2014, p. 633].

\subsection{Gaps in the literature}

There are sparse cross-cultural or cross-national studies about idea generation in NPD, and a huge part of literature on the subject focuses on small, medium sized, and large businesses while overlooking micro-enterprises. Since nowadays start-ups and quick-start enterprises are becoming increasingly popular, this is a very serious research gap. In addition, these businesses tend to offer more userfriendly, time-efficient, economical, and sustainable products or services, and this fact alone can suggest that their new product development process differs from that of more traditional companies. Moreover, there are insufficient guidelines for new product development in high-tech industries presented in the literature, which is a serious gap that in today's business environment needs to be filled. $\mathrm{Nu}$ merous papers, textbooks, and reports about new product idea generation are written in academic, scientific style. This may be of use to academics, scholars, and students, but may prove too specialized for people who run businesses. In gen- 
eral, NPD studies adopt either a managerial perspective or an engineering one. Yet the issue is, in reality, interdisciplinary, and requires combining both these perspectives with considerations about innovation, economy, marketing, entrepreneurship, and art. Moreover, successful idea generation can only be ensured by equipping people with skills in teamwork, networking, communication, conflict management, making guesstimates, etc. Thus, literature on idea generation in new product development ought to be more explorative and adopt a broader understanding of the principles, norms, nature, types, applications, and origins of idea generation.

\section{Results and discussion}

This section discusses the results of the analysis of collected expert opinions (indicated by quotation marks). Generally, the most innovative countries promote 'industrial upgrading', develop 'technology parks and industrial clusters, technology growth centres, labs and lab networks', focus on 'renewable energy', and try to 'minimize waste levels'. Most of them have a 'frank and open bureaucracy' and 'less interventionist policies' and 'offer low-rate long-term loans and give incentives and tax breaks'. Their governments provide a support system in case of failures and act as a big 'contributor and facilitator' who provides 'full support at many stages' from generating an idea to its commercialization. These countries 'facilitate the immigration of elites and multi-talented people' and then use their experience and skills. Immigrants can therefore have a 'huge economic impact' and 'highly contribute to idea generation in NPD'. In this way, the country of destination utilizes their skills while the country of origin has to cover the costs of their acquisition. Good ideas may come from 'less innovative countries yet these ideas are brought into existence in the most innovative countries' because of the lack of a proper protection system in the immigrants' countries of origin. At the same time, in less innovative countries ideation is not 'highly appreciated and nor heavily invested into' and there exist 'no clear strategies for the improvement of high technologies' which are crucial for new idea generation. There are 'inadequate funds for idea generation' and 'idea generation projects tend to be realized by smaller teams or single individuals'. Moreover, 'lack of failure tolerance', 'dominance of opinion leaders' in delivering incentives and 'governmental corruption' are among the factors that differentiate the most from the less innovative countries. Another difference is 'openness to cross-cultural collaboration' and 'incorporation of local products into the intellectual creation cycle'. Establishing 'semi-governmental intermediary institutions for establishing policies in the area of technology' can facilitate the flow of ideas in the society; preplanning a 'national 
innovation strategy' and 'government innovation framework' are also required in order to fill the gap between more innovative and less innovative countries. Tolerance for different 'religious beliefs', awareness of the 'cultural context', and consideration for others' 'individual preferences', 'personal background and life style' even the 'bio-rhythm of persons involved' can have a positive effect on generating new ideas as well.

'Preparing the kids for the future, teaching them manners, responsibility, and respect from an early age, fostering the culture of acceptance, sharing new ideas and tolerating risks in childhood' as well as 'ensuring freedom in the area of idea generation as an educational norm' increase people's self-confidence by teaching systematic ideation methods, and 'giving encouragement for teachers with innovation-supporting qualities' could help less innovative countries minimize the gap between them and more innovative countries. It is advisable for less innovative nations to benchmark from best practices of the most innovative countries and introduce them into their education 'from preschool till scholarship'. If these people learn how to teach their children to be creative, questioning, self-assessor, disciplined, patient, willing to take risks, interactive, and sociable, the young generation will transform their countries.

An idea is a concept without borders. Idea generation is also not bounded by borders, and thus the West and the East can and should enter into a dialogue. The West uses its fiscal and physical support, human capital, methodology, and marketing strategies to secure its supremacy; on the other hand, perhaps the Eastern culture is 'less chaotic, more deep-rooted and more spiritual' than the West. Most of 'Western elites are originally from the East' and most 'concepts are from the East but were developed in the West'. 'Preserving one's own philosophy', 'ethnic manners and local terms of innovativeness', 'local concepts', 'past stories', and 'ancient roots' is helpful in generating locally, ethnically, and nationally relevant ideas, whose realization and commercialization could lead to the creation of unique and strong brands. Interestingly, 'returning to ancient roots' can also be a novel route to idea generation. 'Rediscovering where a person came from', making new steps on his or her old stomping soil and 'touching a dormant part of soul' can inspire individuals to recreate new-fangled ideas. Hardware is easy to buy, decipher, or copy. Brain-ware, software, and system-ware have extra superiority than hardware. In this context, utilizing from 'nationalism' acts as a motivator to produce native notions and domestic ideas. So any eastern or western culture can let their identity (brand, product, teams, service, idea) speak louder and more freely. In a hyper level, localized idea generation and NPD could be run. It is fruitful for Eastern firms; because they can tailor structures and methods based on their own cultures and native contingencies (not imitation from America or Europe). As a solution, Eastern firms can ally and produce their 'own products 
with inspiration of eastern context'. Otherwise west recruits 'smart experts from everywhere of the world' to work for them, since they are creating for Western companies their innovations become the western products. It is advised for Eastern cultures to create their own codes. Like American codes in digital applications, French codes in cosmetics, Italian codes in fashion or German codes in industry.

'Agile, alert and tolerant' government with the 'minimum level of bureaucracy' facilitates NPD. 'Transparency and equality in delivering features' and 'removing complicated procedures' may give the chance to a bigger number of 'potential talents' to 'realize their dreams'. 'Providing soft services', 'right regulations', 'fiscal and physical supports' also 'guarantee or indemnification in case of risk' act as a buffer for 'ideation welcoming ecosystem'. All mentioned items provide a subbase for 'shifting from monetary investment' to 'innovative or idea based investment' which are essential to moving from 'single-source economy' toward a 'knowledge-based multi item economy'. Establishing and well governing of 'interface organizations' (like incubators, technology parks, growth centres, techno-markets, technology accelerators, think tanks), likewise "interaction with NGOs' as a connector or intermediary between government and private sector impresses 'flow of NPD idea generation'. 'Openness to the world' and at the same time 'noticing to local and tribal issues', 'efficient association' with relevant 'global organizations' (such as APO, IASP, UNCTAD, UNIDO, OECD, WIPO), 'looking to migration as the factor and actor of brain circulation' and 'attract entrepreneurs worldwide to start-up in the country' causes 'industrial growth' and 'technological development'. Both of them trigger NPD idea generation and vice versa.

\section{Conclusions}

Idea generation is very important as it leads to economic growth of nations through the development of new technologies and products on the macro level, by raising productivity and competitiveness on the mezzo level, and ultimately by satisfying the needs of individuals and boosting standards of life on the micro level. Yet generating ideas is not enough. Ideas need to be turned into reality because 'ideas are useless unless used' [Levitt, 1963, p. 79]. Many ideas fail in initial stages because of the risky nature of ideation. Scientific evidence indicates very low rate of success of ideas at the end of the innovation funnel. Therefore, a way to optimize ideas' productivity must be found. Creating multiple ideas and merging, combining, or integrating existing ideas is advised in order to access a pool of fresh ideas and cope with the risky nature of idea generation. Idea generation in new product development is vital, yet risky and costly; its nature, norms, and determinants ought to be investigated meticulously. Literature on idea generation should 
be explorative rather than confirmative because of the multidisciplinary nature of this process. It also needs to cinsider a wider context. Since idea generation progresses along with the development of human capital, there is no other way for countries to move forward other than by supporting interdisciplinary human resources with human skills and vision rather than technical excellence. Harmonizing subsystems with systems and hypersystems is a delicate and complex task. The government, as a macro supporter, administrator, and protector, should provide infrastructure and act as a head-hunter in order to find experts and creative individuals, and then 'prepare the scene and handoff the play'. It should 'conduct the innovation orchestra', instead of 'playing every instrument'.

\section{References}

Aaker D.A., Batra R., Myers J.G. (eds.), 1992, Advertising management: Practical perspectives, Prentice-Hall International, Englewood Cliffs, NJ.

Ahuja G., 2000., Collaboration networks, structural holes, and innovation: A longitudinal study, Administrative Science Quarterly, no. 45, http:/faculty.washington.edu/matsueda/ courses/590/Readings/Ahuja\% 202000\%20Networks\%20ASQ.pdf [access: 24.10.2019].

Atkinson R., Wial H., 2008, Boosting productivity, innovation, and growth through a national innovation foundation, Brookings Institution, Washington, DC.

Avital M., Osch W.V., 2013, The generative archetypes of idea work, [in:] Organizational generativity: The appreciative inquiry summit and a scholarship of transformation, ed. D.L. Cooperrider, Emerald Group Publishing, Bingley, UK.

Babbie E., 1990, Survey research methods, Wadsworth Publishing Co., Belmont, CA.

Bacon G., Beckman S., Mowery D., Wilson E., 1994, Managing product definition in high-technology industries: A pilot study, California Management Review, spring.

Baum J.A.C., Calabrese T., Silverman B.S., 2000, Don't go it alone: Alliance network composition and start-ups' performance in Canadian biotechnology, Strategic Management Journal, no. 21, https://www.academia.edu/12999714/Dont_go_it_alone_alliance_network_composition_and_startups_performance_in_Canadian_biotechnology [access: 24.10.2019].

Baumberg B., 2012, Early career reflections, [in:] How many qualitative interviews is enough? Expert voices and early career reflections on sampling and cases in qualitative research, ed. S.E. Baker, R. Edwards, National Centre for Research Methods, UK, http://eprints. ncrm.ac.uk/2273/4/how_many_interviews.pdf [access: 24.10.2019].

Bhuiyan N., 2011, A framework for successful new product development, Journal of Industrial Engineering and Management, no. 4, https://www.researchgate.net/publication/270949146_ A_Framework_for_successful_new_product_development [access: 24.10.2019].

Berends H., Jelinek M., Reymen I., Stultiëns R., 2014, Product innovation processes in small firms: Combining entrepreneurial effectuation and managerial causation, Product Innovation Management, no. 3, https:/www.effectuation.org/wp-content/uploads/2017/06/ Product_Innovation_Processes_in_Small_Fi.pdf [access: 24.10.2019].

Bingham F.G., Quigley C.J. Jr., 1989, Venture team application to new product development, The Journal of Business \& Industrial Marketing, no. 1.

Blythe J., 1999, Innovativeness and newness in high-tech consumer durables, Journal of Product \& Brand Management, no. 5 . 
Brabham D.C., 2013, Crowdsourcing, The MIT Press, Cambridge, MA.

Budd R.W., Thorp R.K., Donohew L., 1967, Content analysis of communications, Macmillan, New York, NY.

Calantone R.J., Schmidt J.B., Song X.M., 1996, Controllable factors of new product success: A cross-national comparison, Marketing Science, no. 4, https://www.researchgate.net/ publication/227442130_Controllable_Factors_of_New_Product_Success_A_CrossNational_Comparison [access: 24.10.2019].

Candy L., Edmonds E.A., 1996, Creative design of the Lotus bicycle: Implications for knowledge support systems research, Design Studies, no. 1, https://www.academia.edu/3339075/ Creative_design_of_the_Lotus_bicycle_implications_for_knowledge_support_systems_ research [access: 24.10.2019].

Cooper R.G., Edgett S.J., 2008, Maximizing productivity in product innovation, Research Technology Management, no. 2, https://www.researchgate.net/publication/263080371_ Maximizing_Productivity_in_Product_Innovation [access: 24.10.2019].

Davari Nikou K., 2017, Terminology, traits, types, and trajectory of new product development, International Business and Global Economy, no. 36.

De Mooij M.K., 2011, Global marketing and advertising: Understanding cultural paradoxes, SAGE Publications, Los Angeles, CA.

Dean T., Griffith D.A., Calantone R.J., 2016, New product creativity: Understanding contract specificity in new product introductions, Journal of Marketing, no. 80.

Fang E., 2008, Customer participation and the trade-off between new product innovativeness and speed to market, Journal of Marketing, no. 4.

Finke R.A., Ward T.B., Smith S.M., 1996, Creative cognition: Theory, research, and applications, The MIT Press, Cambridge, MA.

Flint D.J., 2002, Compressing new product success-to-success cycle time deep customer value understanding and idea generation, Industrial Marketing Management, no. 31.

Flynn M., Dooley L., O'Sullivan D., Cormican K., 2003, Idea management for organizational innovation, International Journal of Innovation Management, no. 4.

Foster J., 2009, How to get ideas, Berrett-Koehler Publishers, San Francisco, CA.

Galvin R., 2015, How many interviews are enough? Do qualitative interviews in building energy consumption research produce reliable knowledge?, The Journal of Building Engineering, no. 1.

Glassman B.S., 2009, Improving idea generation and idea management in order to better manage the fuzzy front end of innovation, PhD dissertation, Purdue University, West Lafayette, IN.

Goldenberg J., Lehmann D.R., Mazursky D., 2001, The idea itself and the circumstances of its emergence as predictors of new product success, Management Science, no. 47.

Goldenberg J., Mazursky, D., 2002, Creativity in product innovation, Cambridge University Press, Cambridge, UK.

Goldenberg J., Mazursky D., 2007, Advertising creativity: Balancing surprise and regularity, [in:] The SAGE handbook of advertising, eds. G.J. Tellis, T. Ambler, SAGE Publications, Los Angeles, CA - London, UK.

Gurteen D., 1998, Knowledge, creativity and innovation, Journal of Knowledge Management, no. 1, http://www.gurteen.com/gurteen/gurteen.nsf/id/kci-article [access: 01.11.2019].

Hanna N., Ayers D.J., Ridnour R.E., Gordon G.L., 1995, New product development practices in consumer versus business products organizations, Journal of Product \& Brand Management, no. 1. 
Herring S.R., Jones B.R., Bailey B.P., 2009, Idea generation techniques among creative professionals, Proceedings of the $42^{\text {nd }}$ Hawaii International Conference on System Sciences, http://orchid.cs.illinois.edu/publications/HICSS-idea-generation-2009.pdf [access: 02.11.2019].

Higgins P.A., 2008, Reducing uncertainty in new product development, PhD dissertation, Queensland University of Technology, Brisbane, Australia.

Hobcraft P., 2011, There are two distinct parts to any innovation funnel, https://paul4innovating.com/2011/08/19/there-are-two-distinct-parts-to-any-innovation-funnel/ [access: 01.11.2019].

Holsti O.R., 1969, Content analysis for the social sciences and humanities, Addison-Wesley Co., Reading, MA.

Jones H.L., 1955, The application of sampling procedures to business operations, Journal of the American Statistical Association, no. 50.

Jung R.E., Wertz C.J., Meadows C.A., Ryman S.G., Vakhtin A.A., Flores R.A., 2015, Quantity yields quality when it comes to creativity: A brain and behavioral test of the equal-odds rule, Frontiers in Psychology, no. 6, https://pdfs.semanticscholar.org/ed15/4bc8a74367ac8535156ea6e857d458ca1b04.pdf [access: 01.11.2019].

Kahn K.B., 2002, An exploratory investigation of new product forecasting practices, The Journal of Product Innovation Management, no. 19.

Kamoche K., Pina e Cunha M., 2001, Minimal structures: From jazz improvisation to product innovation, Organization Studies, no. 5, https://pdfs.semanticscholar.org/6494/64c46bab 1840d40402f8a2eac476df1505c9.pdf [access: 01.11.2019].

Karniouchina E.V., Victorino L., Verma R., 2006, Product and service innovation: Ideas for future cross-disciplinary research, The Journal of Product Innovation Management, no. 23, https://scholarship.sha.cornell.edu/cgi/viewcontent.cgi?article $=1529 \&$ context $=$ articles [access: 01.11.2019].

Kassarjian H.H., 1977, Content analysis in consumer research, Journal of Consumer Research, no. 4.

Kilinc N., Dogan S.D., 2012, Sources of new product ideas of the readymade clothing enterprises in Turkey, International Journal of Business and Management Studies, no. 1, http://www. sobiad.org/eJOURNALS/journal_IJBM/arhieves/2012_Vol_4_n_1/nurgul_kilinc1.pdf [access: 01.11.2019].

Kohn K., 2004, Idea generation in new product development through business environmental scanning: The case of X Car, Marketing Intelligence \& Planning, no. 7, https://pdfs.semanticscholar.org/1c41/8a4848c7876fadaf720ad46a9e46ff76d773.pdf [access: 01.11.2019].

Kotler P., Armstrong G., 2003, Marketing: An introduction, Prentice Hall, Upper Saddle River, NJ.

Kotler P., Keller K.L., 2006, Marketing management, Prentice Hall, New Jersey, NJ.

Krishna A., Kautish P., 2012, Innovation in new service development: The role of customer, International Conference on Trade, Tourism and Management (ICTTM'2012), Bangkok, Thailand, http://psrcentre.org/images/extraimages/26.\%201312555.pdf [access: 01.11.2019].

Kudrowitza M.B., Wallace D., 2012, Assessing the quality of ideas from prolific, early-stage product ideation, Journal of Engineering Design, no. 2.

Latham B., 2007, Sampling? What is it?, Quantitative Research Methods, ENGL 5377, https://docplayer.net/20989579-Sampling-what-is-it-quantitative-research-methodsengl-5377-spring-2007.html [access: 01.11.2019]. 
Levitt T., 1963, Creativity is not enough, Harvard Business Review, no. 3, https://hbr.org/ 2002/08/creativity-is-not-enough [access: 01.11.2019].

Losito M., 2012, What matters for ideation? A cross-level investigation of individual, group and network factors, PhD dissertation, LUISS University, Rome, Italy.

MacNealy M.S., 1999, Strategies for empirical research in writing, Longman, New York, NY.

Marshall M.N., 1996, Sampling for qualitative research, Family Practice, no. 6, https://pdfs.semanticscholar.org/063d/8f0ba824da42f1a55136bdd7aac0f37cc8df.pdf [access: 01.11.2019].

McAdam R., McClelland J., 2002, Sources of new product ideas and creativity practices in the UK textile industry, Technovation, no. 2.

Miller J.D., 2003, Game theory at work: How to use game theory to outthink and outmaneuver your competition, McGraw-Hill, New York - London - Madrid.

Michalko M., 2011, Cracking creativity: The secrets of creative genius, Ten Speed Press, Berkeley, CA.

Morgan T., Anokhin S., Kretinin A., Frishammar J., 2015, The dark side of the entrepreneurial orientation and market orientation interplay: A new product development perspective, International Small Business Journal, no. 7.

No name, 1971, Finding paths from ideas to new products, Management Review, no. 3.

Olson R.W., 1980, The art of creative thinking, Barnes \& Noble, New York, NY.

Oman S.K., Tumer I.Y., Wood K., Seepersad C., 2013, A comparison of creativity and innovation metrics and sample validation through in-class design projects, Research in Engineering Design, no. 24.

Ozer M., 2002, What do we know about new product idea selection?, Department of Management, City University of Hong Kong, project funded by the Center for Innovation Management Studies (CIMS) at North Carolina State University, NC, https://pdfs.semanticscholar.org/d2f5/70697cbbc05381d1647c817dc5c783eb6c13.pdf [access: 02.11.2019].

Paashuis V., 1998, The organisation of integrated product development, Springer Science \& Business Media, London, UK.

Palmer A., 2009, Introduction to marketing: Theory and practice, Oxford University Press, Oxford, UK.

Paulus P.B., Brown V.R., 2007, Toward more creative and innovative group idea generation: A cognitive-social-motivational perspective of brainstorming, Social and Personality Psychology Compass, no. 1.

Pikkarainen M., Codenie W., Boucart N., Heredia Alvaro J.A. (eds.), 2011, The art of software innovation: Eight practice areas to inspire your business, Springer Berlin Heidelberg, Berlin - Heidelberg.

Rochford L., 1991, Generating and screening new product ideas, Industrial Marketing Management, no. 4.

Safarzadeh H., Taleifar R., Salamzadeh Y., Mohammadi F., 2012, An analysis on critical success factors for new product development in SMEs of Iran's food and beverage industries, International Journal of Research in Computer Application \& Management, no. 8.

Shah J.J., Kulkarni S.V., Vargas-Hernandez N., 2000, Evaluation of idea generation methods for conceptual design: Effectiveness metrics and design of experiments, Journal of Mechanical Design, no. 122.

Schemmann B., Herrmann A.M., Chappin M.M.H., Heimeriks G.J., 2016, Crowdsourcing ideas: Involving ordinary users in the ideation phase of new product development, Research Policy, no. 6. 
Surowiecki J., 2005, The wisdom of crowds: Why the many are smarter than the few and how collective wisdom shapes business, economies, societies and nations, Anchor Books, New York, NY.

Shah J.J., Vargas-Hernandez N., 2003, Metrics for measuring ideation effectiveness, Design Studies, no. 24.

Shekar A., 2007, An innovative model of service development: A process guide for service managers, The Innovation Journal: The Public Sector Innovation Journal, no. 1, http://unpan1. un.org/intradoc/groups/public/documents/apcity/unpan031978.pdf [access: 02.11.2019].

Soukhoroukova A., Spann M., Skiera B., 2007, Creating and evaluating new product ideas with idea markets, AMA's 18 th Annual Advanced Research Techniques Forum, New Mexico, http://citeseerx.ist.psu.edu/viewdoc/download?doi=10.1.1.527.7473\&rep=rep1\& type $=$ pdf [access: 02.11.2019].

Soukhoroukova A., Spann M., Skiera B., 2012, Sourcing, filtering, and evaluating new product ideas: An empirical exploration of the performance of idea markets, Journal of Product Innovation Management, no. 1.

Song X.M., Neeley S.M., Zhao Y., 1996, Managing RED-marketing integration in the new product development process, Industrial Marketing Management, no. 6.

Stasch S., Lonsdale R., LaVenka N., 1992, Developing a framework for success of new product ideas, Journal of Consumer Marketing, no. 2.

Tanțău A.D., Mateeşescu C., 2012, Modern business methods of idea generation in the banking sector, Management \& Marketing Challenges for the Knowledge Society, no. 1, https:// pdfs.semanticscholar.org/e801/55b451e0917cd16151b28f5f3ecc382d106e.pdf [access: 02.11.2019].

Toivonen M., Tuominen T., 2009, Emergence of innovations in services, The Service Industries Journal, no. 7.

Torrance E.P., 1964, Role of evaluation in creative thinking, Bureau of Educational Research, University of Minnesota, MN.

Torrance E.P., 1962, Guiding creative talent, Prentice Hall, Englewood Cliffs, NJ.

Toubia O., 2006, Idea generation, creativity and incentives, Marketing Science, no. 5, https:// www.ams-inc.com/pdf/Toubia_MarketingScience.pdf [access: 02.11.2019].

Toyota, (n.d.), Toyota Dream Car Art Contest, http://www.toyota-global.com/events/dream_ car_art_contest [access: 03.01.2016].

Trott P., 2002, Innovation management and new product development, Prentice Hall, Harlow, UK.

Vandenbosch B., Saatcioglu A., Fay S., 2006, Idea management: A systemic view, Journal of Management Studies, no. 2.

Ward T., Smith S., Finke R., 1999, Creative cognition, [in:] Handbook of creativity, ed. R.J. Sternberg, Cambridge University Press, Cambridge, UK.

Wulfen G.V., 2016, www.linkedin.com/home?trk=nav_responsive_tab_home [access: 13.12.2016].

Zhang M.Y., Dodgson M., 2007, High-tech entrepreneurship in Asia: Innovation, industry and institutional dynamics in mobile payments, Edward Elgar Publishing, Cheltenham, UK.

Kamran Davari Nikou (®) k.d.nikoo@gmail.com

Dokuz Eylül University, Graduate School of Social Sciences,

Department of Business Administration, 35390 Buca, Izmir, Turkey 